\title{
Indigenous programmes and evaluation: An excluded worldview
}

\section{Bridgette Masters-Awatere and Linda Waimarie Nikora}

Worldwide the major influence on evaluation practice has come from the United States of America, dominating the field so much that non-dominant (or indigenous) culturally constructed evaluation frameworks are largely excluded and absent. The role and place of Māori people as the indigenous people of this land has influenced the culturally centred development of evaluation in Aotearoa New Zealand. Successive New Zealand governments have adopted neoliberal policies helping to shape health service delivery for, and by, the indigenous Māori peoples of New Zealand. Opportunities to design and deliver Māori-oriented health services were enthusiastically embraced by Māori who were ill-prepared for the additional requirements demanded as a result of accepting service contracts. Within this article the cultural value of whanaungatanga is presented as a source of tension in "By Māori for Māori” externally evaluated health and wellbeing programmes. This article highlights the vulnerable and contentious position that indigenous service providers and external evaluators are placed in when they accept government service-provider contracts. Although service contracts embrace notions of responsiveness and inclusiveness, the continued application of Western-privileged frames continues to marginalise indigenous people and their desires. 


\section{Introduction}

Before the arrival of northern hemisphere explorers to the south seas, Māori, the indigenous people of Aotearoa New Zealand, thrived for centuries confident in their ways of being and, navigating their environments, relationships, and constructions of the world (Kukutai, 2011; Pool \& Kukutai, 2014; Walker, 1990). Accounts from early encounters describe a well-built, muscular and healthy Māori population (Nicholas, 1817), a picture far from that of the present postcolonial reality. Now, Māori live marginalised lives in the presence of a dominant Pākehā or Anglo-European majority and are burdened with negative health, economic, and social concerns that plague indigenous fourth world peoples (Macdonald, 2005; Moghaddam, 1987; Ormond, Cram, \& Carter, 2006; Masters-Awatere, in press; Stubbs, Cochrane, Uerata, Hodgetts \& Rua, in press).

Cappo (2002) observed that a strong sense of social inclusion arises when people feel valued, their differences appreciated, and dignity respected. People connect, engage, and participate, often giving rise to satisfactions in work, health, education, recreation, and future planning. A sense of control, self-efficacy, and liberation is attainable even in the face of dominance, discrimination, and micro-aggressions in one's daily life. These negative aspects of social life, although frustrating and hurtful, are more effectively negotiated through positive engagement rather than imposing solutions defined by others. Social exclusion occurs both within and beyond the interpersonal and enters into the scaffolding of society, its institutions, instruments, and agents. In New Zealand, social policies that actively discriminated against and disadvantaged Māori continued in force until around the 1980s when policies of biculturalism were introduced. Those policies provided avenues for Māori to have grievances against the Crown heard and redressed, and laws supporting earlier policies 
of segregation or assimilation repealed and replaced with more progressive ones (Kelsey, 1999; Walker, 1990). Policy changes have been attended to, yet the dominance of a western worldview continues to be perpetuated in ways that continue to clash with Māori values.

In this article, the authors discuss exemplars from the field of Māori evaluation research to demonstrate the tensions between Māori approaches to service provision and the delivery of outcomes contracted through government service contracts. Externally contracted Māori evaluators are potential mediators of such tensions. We discuss ways in which they navigate the evaluation process while being mindful of Māori worldviews that define and motivate health and wellbeing within Māori communities. We begin by outlining the development of the discipline of evaluation, particularly in the context of the United States where the practice underwent professionalisation and resulted in sophisticated models and applications. We also comment on how the United States has influenced the development of evaluation around the world, including in Aotearoa New Zealand. We then briefly present cases that highlight Māori evaluator experiences of government-commissioned contracts. Our objective is to demonstrate how socially inclusive services can be undermined by evaluations concerned more with outcomes rather than fundamental processes that encourage social inclusion, engagement, and ultimately, individual and collective agency, and self-determination. In doing so, we are ever conscious of the neoliberal agenda that vests responsibility for failure upon the individual, ignoring the part that institutions, and their instruments and agents, play in perpetuating marginalisation and exclusion. At the conclusion of the article, we highlight how whitestream evaluation continues to exclude Māori worldviews and marginalises Māori people. 


\section{Evaluation}

The reflexive capacity to learn from experience and to enact different ways of understanding and being in the world is characteristic of our humanity. If we define evaluation naively, that is, as simply taking stock of a situation, the complexity of life is reduced or overlooked. The modern professional practice of evaluation is somewhat more sophisticated than this. Mathison (2005) has argued that the abstraction and construction of modern evaluation as a scientific paradigm emerged over 100 years ago in the context of post-World War 1 nation rebuilding. Attention to the efficient achievement of outcomes grew with the rise of relief agencies and national support for social programmes to redress poverty, provide access to medical care, address civil rights, and improve education (Posavac \& Carey, 1980; Scriven, 1991). By the 1970 s a bonded relationship between evaluation, government funding, and political climate paved the way for assessments to determine and demonstrate fiscal accountability (Weiss, 1987) giving rise to the need for evaluators to organise professionally. During the 1970s two organisations were formed, the Evaluation Research Society and the Evaluation Network. These two organisations subsequently merged in 1986 to become the American Evaluation Association (http://eval.org) (Kingsbury, 1986).

The mission of the American Evaluation Association (AEA) is "to improve evaluation practices and methods, increase evaluation use, promote evaluation as a profession, and support the contribution of evaluation to the generation of theory and knowledge about effective human action". This complements a vision to "foster an inclusive, diverse, and international community of practice positioned as a respected source of information for and about the field of evaluation" (AEA, n.d.). Here, we draw the reader's attention to the AEA's assumed legitimacy of its culturally bound knowledge system 
and the assertion of an unstated international relevance and standard of respectability. Evaluation practice is shaped by the United States through dissemination and exportation of its knowledge, models, frameworks, and approaches to second- and third-world contexts. ${ }^{1}$ Many around the world lacking first-world resources and capacity simply adopt, with or without critique, such conveniently available first-world generated evaluation knowledge (Moghaddam, 1987; Moghaddam \& Taylor, 1985). The AEA's Program Evaluation Standards Checklist (Guba \& Lincoln, 2001; Scriven, 2005) provides a prime example of Moghadamm's (1987) analysis of the United States' first-world influence over other countries such as Australia, Canada, Germany, Switzerland, the United Kingdom, New Zealand and countries in Africa (Masters-Awatere, 2005).

In 2006, the Aotearoa New Zealand Evaluation Association (ANZEA) was established (http://www.anzea.org.nz) and its clear bicultural mission serves to situate New Zealand differently to other countries. ANZEA emphasises an explicit commitment to Māori people and Māori worldviews in the evaluator competencies (ANZEA, 2011) and then extends this commitment to also include Pasifika in the later released Evaluation Standards for Aotearoa New Zealand (SUPERU \& ANZEA, 2015). The standards reflect a principles-based commitment to guide quality evaluations. They encourage evaluators to be aware of the inadequacies of knowledge from the international domain, and responsive to local community contextual and cultural factors. A sophisticated analysis of dominant evaluation frameworks and the growing neoliberal political environment brings to the foreground the socially unjust pressures borne by Māori. Even

1 Extending on the use of "first world" to refer to developed, capitalist, industrial countries after World War II, Moghaddam and colleagues refer to the publication and dissemination of information that directly influences the development of theories in other countries. Kelsey (1985) provides a New Zealand context and in this article we use these frames when referring to the influence of evaluation theories and models. 
so, simply establishing competency standards does not necessarily rid the discipline of more fundamental biases such as individualism, independence, and empiricism foundational to Western evaluation knowledge.

Evaluation approaches traditionally emphasise measuring outcomes using quasiexperimental designs over other ways of coming into knowledge (Campbell \& Stanley, 1966; Guba \& Lincoln, 1985; Patton, 1990). Although there have been some who work outside this mould (Fetterman, 2002; Feuerstein, 1986; Fitzpatrick, Sanders, \& Worthen, 2004; Morelli \& Mataira, 2010), the trend towards enumerating reality drives funding agencies to value quantifiable outputs over outcomes, the latter often of greater significance to Māori communities. Outputs that justify and account for resources in turn become a dynamic within which to pressure greater efficiencies irrespective of whether the programme had an appropriate effect in, or for, Māori communities (Moewaka Barnes, 2003). This is an example of one kind of bias inherent in the contracting process and subsequent evaluation frame. No matter what frameworks an evaluator opts to use in an evaluation, inaccurate and diminishing results will manifest if those frameworks remain disconnected from notions of privilege, cultural context, or the fundamentally Western foundations on which evaluation research has been built. Complex social environments require sophisticated, responsive, and reflexive approaches.

In the following sections we discuss the notion of whanaungatanga experienced in three external evaluations. The tensions experienced by different stakeholders are used to highlight the challenges Māori programme providers and Māori evaluators face when negotiating a taxpayer-funded service. Critical to our article are the interacting nuances of culture, context, and politics. To contextualise the concept of whanaungatanga we draw on a kaupapa Māori framework to theorise and discuss its complexity. 


\section{A Kaupapa Māori frame}

Kaupapa Mãori is a term often used to refer to research, theory and actions that are "by Māori, for Māori, and with Māori". It signifies an intention to serve an agenda determined by Māori and the need to understand and challenge the forces that serve to maintain disparities (Masters-Awatere, 2015; Pihama, Cram, \& Walker, 2002).

Proponents for indigenous frameworks, such as kaupapa Māori, express a desire for subjective research (Cram, McCreanor, Smith, Nairn, \& Johnstone, 2006; Moewaka Barnes, 2003) that embraces the everyday reality of the people central to research focus (Nikora, Masters-Awatere, \& Te Awekotuku, 2012; Te Awekotuku \& Nikora, 2003). This position evolved in response to criticisms of the asserted objectivity of research as a performance of detachment and distancing and therefore removed from understanding the nuances of culture (Battiste \& Henderson, 2000; Pihama, 2001; Te Awekotuku, 2004). Examples of criticisms include: failing to capture the values and context of local communities (Maaka \& Fleras, 2005; Smith, 1997; Te Awekotuku, 1991); furthering an agenda external to the community under examination (Bishop, 1994; Smith, 1999); and not meeting obligations to protect the intellectual property of their informants (Indiggena \& Kothari, 1997; Masters, 2000). The absence of Māori worldviews in the design and analysis of research and evaluation in New Zealand contributed to community backlash with respect to research on Māori.

An example of a very early study set in a kaupapa Māori frame is that led by Elizabeth Murchie (1984). It was organised by the Māori Women's Welfare League (MWWL), a prominent, reputable Māori organisation in New Zealand's social and commercial environment. Members of the MWWL-mothers, grandmothers, aunts, and cousins - went to the homes of Māori whānau to gather 
information about their health, wellbeing, income, and aspirations for the future. The short time frame of 6 weeks within which these women as researchers had to gather sensitive information was only possible because the women: already had a relationship in the community (Bevan-Brown, 1998; Te Awekotuku, 2004); already knew that reciprocity had minimal boundaries (Moewaka Barnes, 2000); were committed to building an ongoing relationships (Tibble, 1984); and were secure in the knowledge that some relationships existed before the project (Pihama et al., 2002). This study opened the way for Māori-initiated and designed research that generated useful and reliable data about specific Mãori health issues. The report, titled Whaiora, demonstrated that Māori cultural approaches used in the research process could provide an opportunity to advance Māori health. Such detailed information was possible because of the cultural practices engaged by the women who collected the information. This study demonstrated that research by Māori, for Māori, and involving Māori, demands recognition of our whanaungatanga-our connectedness and relationality to one another.

\section{Expressions of whanaungatanga}

Māori researchers who do not conform to Māori cultural expectations incur a social cost upon themselves and their family (Nikora, 2007). Māori must navigate through contemporary society as an ethnic minority in the face of a dominant majority (Nikora et al., 2012). At the same time, they are challenged to maintain genealogical connections and customary practices that reinforce allegiances of extended families (whānau) as part of a political and caring community (Walker, 1992). As an ambilineal society (Sinclair, 2001), Māori can claim connections from both parents. With an ability to claim access and resources to both sides of ancestry also comes dual responsibility back to each of those lines. Pā Henare Tate (1990) 
describes the nature of Māori spirituality; spirit is everywhere and in everything:

Why do families of such people return to the 'back of beyond' in droves for a tangi [mourning rituals]? Because it is a way of acknowledging the dignity of the person who has died, and the dignity of their ancestors and the whole whānau. And by returning to the source of tapu [the sacred], the family and friends are invigorated and spiritually replenished (Tate, 1990, pp. 88-89).

Participating in making and sustaining a sense of belonging and obligation to one another lies at the heart of whanaungatanga. Below we present four expressions of whanaungatanga within the context of an external evaluation. Each experience highlights how whānau express a desire for engagement and accountability. We examine the ways Māori evaluators responded to whānau obligations while undertaking a government contract, and posit that the contracting process continues to be a source of stress for Māori programme stakeholders.

\section{E hoki ki te ukaipō (return home)}

Eruera $^{2}$ joined a research unit 6 months into a 3-year evaluation contract. The unit was tasked with evaluating the success of a national programme aimed at reducing diabetes. Eruera was brought onto the team, comprising both Māori and Pākehā, to look specifically at delivery to marae (traditional Māori community facilities). During his first couple of months in the position Eruera travelled with team members to visit various marae to discuss the national diabetes programme; one marae was his own. Raised by his grandparents, Eruera grew up on his marae. As a young adult, Eruera moved to the city to seek a university education and to pursue employment opportunities. Now in his late 30s the evaluation had brought Eruera "home".

2 Pseudonyms have been used for all names, places and other identifying information presented in this article. 
For the remainder of the evaluation Eruera returned to his marae 3-4 times per year to conduct interviews, monitor food-safety practices before events, and attend relevant functions on behalf of the evaluation team. With each visit Eruera noticed that he was called on to perform duties to represent the mana (prestige) of his family and marae. Although proud to represent his whānau, and grateful for the opportunities to take his own children home, Eruera was stressed by the cultural duties that added to his evaluation workload. He also observed that Pākehā team members were only invited to the public events, and that other Māori team members were busy performing similar whānau duties at their own marae.

Within the accolades whānau lauded upon Eruera for his success in the city, were messages to return home for the long term. Whānau members of all ages would ask "where have you been, why can't you come back more often", and "do you think the city is a place for your children, look how happy they are here?" Such comments contributed to the tension and obligation Eruera experienced while working on the evaluation.

Cultural nuances were reflected in the invitations issued and the questions asked by whānau. To understand the sense of obligation and accountability that exists for Māori (Nikora, 2007) means that one must first be aware of them. Contained within Eruera's experience is an example of both privilege and obligation afforded Māori evaluators that are not otherwise experienced by Pākehā colleagues (Macfarlane, 2008).

\section{He toka tūmoana he ākinga nā ngā tai (A standing rock in the sea lashed by the tides)}

Manuera is a self-employed evaluation practitioner who has managed his own business since leaving a central government position more than 15 years ago. The majority of his contracts are to large 
government agencies, but sometimes Manuera does small, shortterm evaluations for Māori, iwi (tribal) or not-for-profit groups. In this example, an iwi health provider asked Manuera to complete an evaluation of their service within 5 weeks or they would face losing funding for a service contract.

A government agency had been part funding an employee within the iwi health provider agency for 3 years. No clear reporting structure had been established, so the provider created a reporting template for the funder. Without feedback to the contrary, the provider assumed this met the contractor's expectations. In the last year of a 3-year contract the project manager of the government agency announced that it was time for an evaluation report that contained sophisticated statistical analyses of the progress and impact made towards reducing youth uptake of cigarettes and other drugs.

Manuera did not whakapapa (have genealogical connections) to the area, but his wife and children did. Since leaving Wellington Manuera had settled in the region to raise his children. The service coordinator for the iwi provider had children of the same age as Manuera's children who attended the same kura (a Māori culturally centred school). She approached Manuera for assistance to salvage matters for the iwi provider. Although Manuera did not really want to do the work, he did agree to assist them. An initial conversation with the provider revealed insufficient capability to meet the administrative requirements demanded by the project manager. Furthermore, neither the iwi provider nor the Ministry had been collecting relevant data that would enable reporting on specific rates of reduction as expected in the evaluation. Manuera negotiated with a reluctant project manager to shift the evaluation emphasis towards a qualitative approach to capture youth narratives about their connection to their identity, and factors that drew them towards healthy lifestyles. The outcome was a positive one for the provider but would not have been 
achieved without its staff reaching out for help and expertise from their own relational networks. This is whanaungatanga in practice. That they recognised the need for negotiation and stepped up to the task was a performance of care. Manuera was able to design an evaluation that captured narratives that explained how staff delivered on their cultural and community responsibilities, thus reducing tensions between provider, funder, and evaluator. More importantly, the community retained a much needed programme enabling the service-users to continue a pathway towards being free from nicotine addiction.

This example speaks to the importance of remaining responsive to the services being evaluated and understanding of their context and political environment. Evaluators become part of a whānau of interest, if but for a short time, and that whānau has a responsibility of care as does the evaluator. When hired to conduct an evaluation, measuring success against predetermined targets preempts participation by Māori and reflects interests held by others external to the programme and community. In effect, such targets and success measures can be irresponsibly, bluntly, and ignorantly imposed with damage ensuing. An evaluation that draws from culturally inadequate tools can produce culturally inferior results. In this situation Manuera was able to lobby for the inclusion of cultural perspectives as desired by the provider while negotiating a compromise for the two stakeholder groups involved (i.e., the government agency as the funder, and the iwi service provider). As this example illustrates, experienced evaluators sometimes negotiate a more culturally responsive frame before a contract is finalised (Masters-Awatere, 2015).

\section{Ko te mauri he mea huna ki te moana (the living force is hid- den in the sea)}

The multilayered complexity of government-funded programmes that are "owned" by the local providers and "lived" by the communities 
that engage them, means that it is difficult for an evaluator to satisfy each stakeholder groups' expectations. The "added value" cultural understanding and indigenous perspective brings to the quality of an evaluation can sometimes go unrecognised (Wehipeihana, 2008). The following example from Peata highlights the work she did to improve the cultural worth of an evaluation.

Peata works in a Ministry office and has worked in the government sector for more than 10 years. She is the team leader charged with overseeing three concurrent evaluations of regionally delivered Māori-focused programmes. One of those evaluations is specifically focused on a programme delivered to the region, including the rural community, where she has whakapapa ties. As the team leader, she was not involved in data collection or relationship management with the regions. Her role was to ensure the work was completed on time and was of an acceptable quality for the Minister to present to Cabinet. If additional resources were required to achieve this outcome, she was charged to find them.

Amongst the team 'doing' the evaluation was a mature Pākehā (New Zealander of predominantly European descent) member named Sandra who took self-appointed leadership over the team comprising two Māori researchers and another younger Pākehā. As the team began compiling the evidence for the reports, team members expressed their concerns about the message contained within the report. Peata worked closely with the team: she advised them on how to manage the tone of the report; she shared drafts with a cultural analysis; and provided a mentor to guide the teams writing efforts, recognising the negative impact policies and funding structures have had on Māori communities. After several drafts, Peata was still unhappy with the tone and lobbied for a short-term contract with a Māori evaluation expert to overwrite the report. Without the power and the resources to do this, the report presented to the 
Minister would have looked very similar to reports of the past that shaped policies which failed Māori.

The major influence on the initial design and scope of the evaluation came from the programme/evaluation funder. Those commissioning the work sought answers to meet their own needs, and could have excluded the perspective of those for whom the programme was designed, implemented, and intended to effect. This example demonstrated the sociocultural and sociopolitical nature of evaluation. Born from her Māori connectedness and relationality, Peta brought a keen awareness and responsibility to ensuring the report acknowledged the cultural reality of the communities concerned and their need to be empowered. Without this insight and Peta's sense of obligation, the evaluation would have been a "whitestream evaluation" excluding the worldview of those targeted in the programme.

\section{Discussion}

This article has briefly presented the whanaungatanga interactions of three Māori evaluators undertaking contracts for different government agencies. Each situation demonstrates the importance of being "known" amongst Māori communities. Within Māori contexts, "to be known is to be seen". The cultural value placed on being "seen in the community" is a prominent theme repeatedly presented by indigenous researchers. Fiona Cram (2001), Kataraina Pipi (Pipi et al., 2002), and Linda Smith (1999) refer to the expectation by Māori that an evaluator will be part of the community, committed to contributing to positive change (Kahakalau, 2004) and accountable to that community (Walker, 1987). Failure to meet any one of these expectations would be to act outside cultural expectations and would therefore invite at best a reprimand, at worst, exclusion (Nikora et al., 2012). These experiences demonstrate how the expectations of whanaungatanga can support and challenge evaluators. 
Māori stakeholders and Māori evaluators understand the imperatives of whanaungatanga, a practice value fostered within whānau, hapū, and iwi, and integral to familial relationships. The practice of whanaungatanga in communities and providers is manifested through processes of accountability, relationship engagements, and cultural obligations. For Māori evaluators doing contracts, the recognition and discharge of whanaungatanga obligations is apparent in different ways. For some, there were intensified self-identification tensions, heightened stress to meet cultural expectations; for others, there was a familiarity that was embraced. Such familial connections held by Māori evaluators affirm a continued connection to the Māori world. Emphasis, within Māoridom, on whānau, whanaunga, and whanaungatanga (Bishop, 1998; Durie, 1994; Stein \& Mankowski, 2004) reflect the importance of encounters (Hodgetts, Barnett, Duirs, Henry, \& Schwanen, 2005; Masters, Levy, Thompson, Donnelly, \& Rawiri, 2004) that serve to remind Māori of their connections to one another (Hudson, Milne, Reynolds, Russell, \& Smith, 2010; McKegg, 2005).

Effective evaluators have to be mindful of the ways in which worldviews, culture, and social institutions prime how people perceived the opportunities and threats facing them (Royal, 2003). Evaluators who exclude the diverse perspectives within communities maintain the often-imbalanced power status quo. The exclusion of Māori community perspectives does not contribute to a Māori agenda and further silences the community's want for accountability. When the drive for an evaluation has originated from the agenda of a dominant and powerful group external to the community and programme being examined, an evaluator needs to aware of, and have strategies to counter, the privileges which the contracting process affords the dominant group.

Many Māori have made contributions to the discussion on kaupapa Māori theory, research, and evaluation. Regardless of the 
various positions we have taken on the strengths and weaknesses of a kaupapa Māori approach, there is one point of agreement-kaupapa Māori research can only originate from, and therefore be driven by, the people. The position reflects a desire to serve a "by Māori for Māori" agenda of theory, research, and service provision (Cram, Lenihan, \& Reid, 2000; Eketone, 2008; Masters-Awatere, 2005; Moewaka Barnes, 2000).

Mistrust of research (and by extension, mistrust of Pākehā) by Māori originates from the experience of exploitation and violation (Battiste \& Henderson, 2000; Smith, 1999). The interrelatedness and interconnectedness of the indigenous worldview acknowledged within Māori culture is lived through whanaungatanga. For Māori this tangible and intangible connection demands the acknowledgement, a position and responsibility often found wanting in evaluations.

Since the 1990s governments have been making an effort to include Māori cultural perspectives. The following statement from the Labour Party manifesto (1999) provides an example of a desire for progressive policies:

... [Labour acknowledge] policies that were designed to assist Māori have failed because they did not take into account the traditional whānau, hapū and iwi structures of society in which power comes from the bottom up... it is time to recognise and support whānau, hapū and iwi to find their own solutions (Labour Party, 1999, p. 2).

The state is capable of progressive policies that enhance indigenous rights, yet it is equally capable of regressive measures that exclude and exploit (Kelsey, 1990; Spoonley, 1995). The multilayered nuances of diverse stakeholder needs create a complexity. Although the use of evaluation findings to inform policy has been patchy (State Services Commission, 2003), the enthusiastic embrace of a resultsbased accountability approach (Friedman, 2005) into government 
contracting and reporting systems (Ministry of Business, Innovation and Employment, 2015) demonstrates a capacity for change that includes the continued possibility to evolve responsive evaluation strategies.

\section{Conclusion}

In this article the authors have highlighted the complex cultural obligations that exist for evaluators. Across multiple stakeholder groups there are layered relationships and interactions that manifest for Māori evaluators as obligation and accountability. The absence of cultural knowledge explicitly positioned within research has been to the detriment of Māori programmes designed and delivered from a culturally centred position (Cram, 1995, 2001; Cunningham, 1998; Davidson-Rada \& Davidson-Rada, 1992). Evaluations that do not consider the intersection of culture with processes of capitalism, labour, and economic power will fail to do justice to the contexts and the lived experiences of people (Grande, 2003; Taylor, 2003).

Evaluation has been closely linked to political agendas; and government positioning means that a cultural lens in an evaluation of culturally centred programmes is essential. In his report Measuring Mãori Well-being, Mason Durie (2006) advocated for measures to reflect the way a community is organised and the positive attributions that can result for the people concerned. He further argued that the "measurement of Māori well-being requires an approach that is built to reflect Māori worldviews, especially the close relationship between people and the environment" (Durie, 2006, p. 15). Communities are a wealth of knowledge and, through shared opportunities, a sense of wellbeing can be achieved (Durie, 2001; Hodgetts et al., 2010; Lynch, 2002).

We contend that a commissioning agency, cognizant of the ways evaluation can be used, should not privilege "objectivity", but instead recast evaluation as socioculturally situated. Evaluation should be 
determined by the appropriateness of its application with a keen awareness of context rather than by its method. Evaluations of Māori service programmes that ignore the role of Māori culture or values do not contribute to positive social transformation.

Although evaluators are stakeholders, they are a different type of stakeholder (Abma, 2006; Clayson, Castaneda, Sanchez, \& Brindis, 2002). Some could argue that evaluators have a less "vested interest" in whether a programme continues or not. However, as demonstrated in these experiences, Māori evaluators have a high level of obligation and accountability to the Māori communities delivering these types of services whether or not they have a genealogical connection. If external evaluations enacted an engaged relationship that incorporated a cultural lens on the analysis of the programmes under examination, then a Māori worldview is central to the design, analysis, and reporting. Presented in this article were snippets of how evaluators worked to ensure that Māori cultural frames were included in their work.

This article has provided examples of how these indigenous evaluators managed complex stakeholder relationships while also navigating cultural frames. Their approach fought to include those for whom the programme targeted. We posit that programmes funded on the basis of a Māori worldview to effect change should also be evaluated against standards from that same worldview.

\section{Acknowledgements}

The authors would like to acknowledge the people presented within the examples for their permission to discuss their experiences in this article.

\section{Conflict of interests}

The authors declare no conflict of interests. 


\section{References}

Abma, T. A. (2006). The social relations of evaluation. In I. Shaw, J. Green \& M. Mark (Eds.), The Sage handbook of evaluation (pp. 184-199). London, UK: Sage.

American Evaluation Association. (n.d.). About AEA [website]. Retrieved from http://www.eval.org/p/cm/ld/fid=4

ANZEA. (2011). ANZEA Evaluator Competencies Project.

Retrieved from http://www.anzea.org.nz/index. php?option=com_content $\&$ view $=$ article $\&$ id $=91 \&$ Itemid $=99$

Battiste, M., \& Henderson, J. Y. (2000). Protecting indigenous knowledge and heritage: A global challenge. Saskatoon: Purich Publishing.

Bevan-Brown, J. (1998). By Māori, for Māori, about Māori - is that enough? In T. P. Hauora (Ed.), Te Oru Rangahau: Mãori Research \& Development Conference (pp. 231-249). Massey University, Palmerston North: Te Pūtahi-ā-Toi.

Bishop, R. (1994). Initiating empowering research? New Zealand Journal of Educational Studies, 29(1), 175-188.

Bishop, R. (1998). Whakawhānaungatanga as a research process. In T. P. Hauora (Ed.), Te Oru Rangahau: Maori Research \& Development Conference (pp. 133-138). Massey University, Palmerston North: Te Pūtahi-ā-Toi.

Campbell, D. T., \& Stanley, J. C. (1966). Experimental and quasiexperimental designs for research. Skokie, Ill: Rand McNally.

Cappo, D. M. (2002). Social inclusion as a determinant of mental health and well being. VicHealth, Research Summary, 2.

Clayson, Z., Castaneda, X., Sanchez, E., \& Brindis, C. (2002). Unequal power -changing landscapes: Negotiations between evaluation stakeholders in Latino communities. American Journal of Evaluation, 23(1), 33-44.

Cram, F. (1995). Ethics and cross-cultural research. Auckland: University of Auckland. 
Cram, F. (2001). Rangahau Māori: Tona tika, tona pono-The validity and integrity of Māori research. In M. Tolich (Ed.), Research Ethics in Aotearoa New Zealand (pp. 35-52). Auckland: Pearson Education.

Cram, F., Lenihan, T. M., \& Reid, P. (2000). Māori research development: Kaupapa Māori principles, procedures and practices. Provider interviews: Summary report. Wellington: Te Puni Kōkiri.

Cram, F., McCreanor, T., Smith, L. T., Nairn, R., \& Johnstone, W. (2006). Kaupapa Māori research and Pākehā social science: Epistemological tensions in a study of Māori health. Hülili: Multidisciplinary Research on Hawaiian Well-Being, 3(1), 41-68.

Davidson-Rada, J., \& Davidson-Rada, M. (1992). Beyond Band-Aid: a guide to effective health \& wellness programmes in New Zealand workplaces. Wellington: Authors.

Durie, M. (1994). Whaiora: Mãori health development. Auckland: Oxford University Press.

Durie, M. (2001). Mauriora: The dynamics of Mãori health. Melbourne, VIC: Oxford University Press.

Durie, M. (2006). Measuring Mãori wellbeing Kei te pēwhea tō whānau? Exploring whānau using the Mãori Social Survey. Wellington: New Zealand Treasury/Statistics New Zealand.

Eketone, A. (2008). Theoretical underpinnings of kaupapa Māori directed practice. Mai Review, 1. Retrieved from http://www.review.mai.ac.nz

Fetterman, D. (2002). Empowerment evaluation: Building communities of practice and a culture of learning. American Journal of Community Psychology, 30, 89-102.

Feuerstein, M. (1986). Partners in evaluation: Evaluating development and community programmes with participants. London, UK: MacMillan Education.

Fitzpatrick, J. L., Sanders, J. R., \& Worthen, B. R. (2004). Program evaluation: Alternative approaches and practical guidelines (3rd ed.). Boston, MA: Pearson. 
Friedman, T. (2005). The world is flat: A brief history of the twenty-first century. New York, NY: Farrar, Straus and Giroux.

Grande, S. (2003). Whitestream feminism and the colonialist project: A review of contemporary feminist pedagogy and praxis. Educational Theory, 53 (Summer, no 3), 329-346.

Guba, E., \& Lincoln, Y. (1985). Effective evaluation: Improving the usefulness of evaluation results through responsive and naturalistic approaches (4th ed.). San Francisco, CA: Jossey-Bass.

Guba, E., \& Lincoln, Y. (2001). Guidelines and checklist for constructivist (aka fourth generation) evaluation. Retrieved from http://www.wmich.edu/ evalctr/archive_checklists/constructivisteval.pdf

Hodgetts, D., Barnett, A., Duirs, A., Henry, J., \& Schwanen, A. (2005). Māori media production, civic journalism and the foreshore and seabed controversy in Aotearoa. Pacific Journalism Review, 11(2), 191-208.

Hodgetts, D., Drew, N., Sonn, C., Stolte, O., Nikora, L., \& Curtis, C. (Eds.). (2010). Social psychology and everyday life. New York, NY: Palgrave MacMillan.

Hudson, M., Milne, M., Reynolds, P., Russell, K., \& Smith, B. (2010). Te ara tika: Guidelines for Māori research ethics: A framework for researchers and ethics committee members. Auckland: Health Research Council.

Indīgena, F. S., \& Kothari, B. (1997). Rights to the benefits of research: Compensating indigenous peoples for their intellectual contribution. Human Organization, 56(2), 127-137.

Kahakalau, K. (2004). Indigenous heuristic action research: bridging western and indigenous research methodologies. Hulili: Multidisciplinary Research on Hawaiian Well-Being, 1(1), 19-33.

Kelsey, J. (1985). Decolonization in the "First World": Indigenous peoples' struggles for justice and self-determination - A discussion of the Treaty of Waitangi and the Bill of Rights. Windsor Yearbook of Access to Justice, 5, 102-141. 
Kelsey, J. (1990). A question of honour? Labour and the Treaty 1984-1999. Wellington: Allen and Unwin.

Kelsey, J. (1999). Reclaiming the future: New Zealand and the global economy. Wellington: Bridget Williams Books.

Kingsbury, N. (1986). Coming together: Evaluation Network and Evaluation Research Society share common business agendas at Evaluation '85 leading to the American Evaluation Association. American Journal of Evaluation, 7(1), 107-110. doi:10.1177/109821408600700118

Kukutai, T. (2011). Building brown boundaries: Defining Māori population in New Zealand. In P. Skold \& P. Axelsson (Eds.), Indigenous peoples and demography: The complex relation between identity and statistics (pp. 33-54). Oxford, UK: Bergham Books.

Labour Party. (1999). He pütahitanga hou. Wellington: Author.

Lynch, J. (2002). Working in partnership. In J. Drage (Ed.), Empowering communities?: Representation and participation in New Zealand's local government (pp. 258-276). Wellington: Victoria University Press.

Maaka, R., \& Fleras, A. (2005). The politics of indigeneity: Challenging the state in Canada and Aotearoa New Zealand. Dunedin: University of Otago Press.

Macdonald, T. H. (2005). Third world health, hostage to first world wealth. Oxon, UK: Radcliffe Publishing.

Macfarlane, A. H. (2008). Kia hiwa rā! Listen to culture: A counter narrative to standard assessment practices in psychology. The Bulletin, 111, 33-36.

Masters-Awatere, B. (2005). Exploring cultural competency in evaluation. In P. Oliver (Ed.), Evaluation: Making it real in Aotearoa New Zealand: Leading by example, leading by Association (pp. 45-53). Tauhara, Taupo: Auckland Evaluation Group.

Masters-Awatere, B. (2015). "That's the price we pay": Kaupapa Maori programme stakeholder experiences of external evaluation. Unpublished doctoral thesis, University of Waikato, Hamilton. 
Masters-Awatere, B. (in press). A game of Slides and Ladders: Māori health providers and funders. In S. Groot, C. vanOmmen, B. Masters-Awatere, $\&$ N. Tassell-Matamua (Eds). A class in the making: Precarity in Aotearoa. Auckland: Massey University Press.

Masters, B. (2000). Researching the process of auahi kore for marae. Wellington: Health Sponsorship Council.

Masters, B., Levy, M., Thompson, K., Donnelly, A., \& Rawiri, C. (2004). Creating whanaungatanga: Kaupapa Māori support in the Psychology Department at the University of Waikato. Network, 16(2), 29-36.

McKegg, K. (2005). Developing an evaluation training and development network for New Zealand. In P. Oliver (Ed.), Evaluation: Making it real in Aotearoa New Zealand (p. 44). Tauhara, New Zealand: Auckland Evaluation Group.

Ministry of Business, Innovation, and Employment. (2015). AnnualrReport 2014/2015: For the year ended 30 June 2015. Wellington: Author. Retrieved from http://www.mbie.govt.nz/publications-research/publications/mbiecorporate/MBIE\%20Annual\%20Report\%202014-15.pdf.

Moewaka Barnes, H. (2000). Kaupapa māori: Explaining the ordinary. Pacific Health Dialogue, 7(1), 13-16.

Moewaka Barnes, H. (2003). Māori and evaluation: Some issues to consider. In N. Lunt, C. Davidson \& K. McKegg (Eds.), Evaluating policy and practice: A New Zealand reader (pp. 146-151). Auckland: Pearson Education New Zealand.

Moghaddam, F. (1987). Psychology in the three worlds: As reflected by the crisis in social psychology and the move toward indigenous third-world psychology. American Psychologist, 42, 912-920.

Moghaddam, F., \& Taylor, D. M. (1985). Psychology in the developing world: An evaluation through the concepts of "dual perception" and "parallel growth”. American Psychologist, 40, 1144-1146.

Morelli, P., \& Mataira, P. (2010). Indigenizing evaluation research: A long awaited paradigm shift. Journal of Indigenous Voices in Social Work, 1(2), $1-12$. 
Nicholas, J. L. (1817). Narrative of a voyage to New Zealand. London, UK: John Black and Sons.

Nikora, L. (2007). Mãori social identities in New Zealand and Hawai'i. Unpublished doctoral thesis, University of Waikato, Hamilton.

Nikora, L., Masters-Awatere, B., \& Te Awekotuku, N. (2012). Final arrangements following death: Māori indigenous decision-making and tangi. Journal of Community \& Applied Social Psychology, 22(5), 400-413.

Ormond, A., Cram, F., \& Carter, L. (2006). Researching our relations: Reflections on ethics and marginalisation. AlterNative: An international Journal of Indigenous peoples. 2(1), Special supplement 2006Marginalisation, pp. 175-192 Retrieved from: http://www.content. alternative.ac.nz/index.php/alternative/article/view/141/154

Patton, M. (1990). Qualitative evaluation and research methods (2nd ed.). Newbury Park, CA: Sage.

Pihama, L. (2001). Tīhei mauri ora-honouring our voices: Mana wahine as a kaupapa Mãori theoretical framework. Unpublished doctoral thesis, University of Auckland.

Pihama, L., Cram, F., \& Walker, S. (2002). Creating methodological space: A literature review of kaupapa Māori research. Canadian Journal of Native Education, 26(1), 30-43.

Pool, I., \& Kukutai, T. (2014, 1 April). Taupori Mãori-Māori population change: Population changes, 1969-1840. Retrieved from http://www.TeAra. govt.nz/en/taupori-maori-maori-population-change/page-1

Posavac, E. J., \& Carey, R. G. (1980). Program evaluation: Methods and case studies (2nd ed.). New Jersey: Prentice-Hall.

Royal, T. A. C. (Ed.). (2003). The woven universe: Selected writings of Rev. Mãori Marsden. Ōtaki: The Estate of Rev. Māori Marsden.

Scriven, M. (1991). Evaluation thesaurus (4th ed.). Newbury Park, CA: Sage.

Scriven, M. (2005). Key evaluation checklist. Retrieved from www.wmich.edu/evalctr/archive_checklists/kec_april05.pdf 
Sinclair, K. (2001). Mischief on the margins: Gender, primogeniture and cognatic descent among the Maori. In L. Stone (Ed.), New directions in anthropological kinship (pp. 156-174). Lanham, MD: Rowman \& Littlefield.

Smith, G. H. (1997). The development of kaupapa Māori: Theory and praxis. Unpublished doctoral thesis, University of Auckland.

Smith, L. T. (1999). Decolonizing methodologies: Research and indigenous peoples. Dunedin: Zed Books and University of Otago Press.

Spoonley, P. (1995). Racism and ethnicity (2nd Edition ed.). Auckland: Oxford University Press.

State Services Commission. (2003). Doing the right things and doing them right: Improving evaluative activity in the New Zealand state sector. Wellington: State Services Commission

Stein, C., \& Mankowski, E. S. (2004). Asking, witnessing, interpreting, knowing: Conducting qualitative research in community psychology. American Journal of Community Psychology 33, 21-35.

Stubbs, T., Cochrane, W., Uerata, L., Hodgetts, D., \& Rua, M. (in press). The Māori precariat: A silhouette. In S. Groot, C. vanOmmen, B. Masters-Awatere, \& N. Tassell-Matamua (eds). A class in the making: Precarity in Aotearoa. Auckland: Massey University Press.

SUPERU, \& ANZEA. (2015). Evaluation standards for Aotearoa New Zealand. Wellington: Author. Retrieved from http://www.superu.govt.nz/ sites/default/files/Superu_Evaluation_standards.pdf.

Tate, H. (1990). The unseen world. New Zealand Geographic, (5), 87-91.

Taylor, R. (2003). An indigenous perspective on evaluations in the intercultural context: How far can one throw a Moree boomerang? Evaluation Journal of Australasia, 3(2), 44-53.

Te Awekotuku, N. (1991). He tikanga whakaaro: Research ethics in the Mãori community. Wellington: Manatū Māori 
Te Awekotuku, N. (2004). Mā hea-which way? Mo te aha—what for? Too many questions, not enough answers, for Māori on the march. The Bulletin, 103(December), 29-33.

Te Awekotuku, N., \& Nikora, L. (2003). Ngā taonga o Te Urewera: A report prepared for the Waitangi Tribunal's Urewera District inquiry (Wai 894, doc B6). Hamilton: University of Waikato. Retrieved from http://hdl.handle. net/10289/784

Tibble, T. K. (1984). Speech at Hui Taumata 1984. In Department of Māori Affairs (Ed.), Paper pesented at the Maori Economic Development Summit Conference - Hui Taumata Conference (conference background papers, paper 58). Wellington: Department of Māori Affairs.

Walker, R. (1987). Ngā tau tohetohe: Years of anger. Auckland: Penguin Books.

Walker, R. (1990). Ka whawhai tonu matou: struggle without end. Auckland: Penguin.

Walker, R. (1992). Marae: A place to stand. In M. King (Ed.), Te ao hurihuri: Aspects of Maoritanga (pp. 15-27). Auckland: Reed.

Wehipeihana, N. (2008). Indigenous evaluation: A strategic objective of the Australasian Evaluation Society. Evaluation Journal of Australasia, 8(1), 40-44.

Weiss, C. (1987). Where politics and evaluation meet. Newbury Park, CA: Sage Publications. 


\section{Glossary of Māori words and terms ${ }^{3}$}

\begin{tabular}{|c|c|}
\hline Aotearoa & original Māori name for New Zealand \\
\hline hapū & $\begin{array}{l}\text { (noun) subtribe; (adjective) the political unit of presettlement } \\
\text { Māori society, to be pregnant }\end{array}$ \\
\hline hui & $\begin{array}{l}\text { gathering or meeting operating under tīkanga Māori, for example } \\
\text { Hui Whakaoranga - } 1984 \text { Māori health conference }\end{array}$ \\
\hline iwi & $\begin{array}{l}\text { tribe, aggregation of hapū sharing a traditional link, extended } \\
\text { kinship group }\end{array}$ \\
\hline kai & food, sustenance, eat \\
\hline kaupapa Māori & Māori focused, a Māori way, Māori ideology \\
\hline mana & authority, integrity, standing, prestige \\
\hline Māori (noun) & indigenous people of Aotearoa, original inhabitant \\
\hline māori (adjective) & normal, native, indigenous \\
\hline marae & the open space in front of the wharenui/ meeting house \\
\hline mātauranga Māori & Māori epistemology \\
\hline Pākehā & $\begin{array}{l}\text { the settlers, may refer to all non-Māori, or be restricted to New } \\
\text { Zealanders of European descent }\end{array}$ \\
\hline Pasifika & $\begin{array}{l}\text { a term used to describe migrants from the Pacific region and their } \\
\text { descendants who call Aotearoa home }\end{array}$ \\
\hline tangi & to cry, mourn, weep, weep over \\
\hline tangihanga & rites for the dead, funeral \\
\hline tapu & $\begin{array}{l}\text { be sacred, prohibited, restricted, set apart, forbidden, under atua } \\
\text { (deity) protection }\end{array}$ \\
\hline whānau & family, to give birth, born \\
\hline whanaunga & family, extended family \\
\hline whanaungatanga/ & creating and sustaining relationships between relations and close \\
\hline
\end{tabular}

\section{The authors}

\section{Bridgette Masters-Awatere and Linda Waimarie Nikora Institution: Māori \& Psychology Research Unit, University of Waikato, Private Bag 3105, Hamilton, 3020, New Zealand} Send all correspondence about this article to: bridge@waikato.ac.nz

3 Unless otherwise stated translations are sourced from: Williams, H.W. (1971). Dictionary of the Mãori language (7th ed.) Wellington: GP Publications; or The online Māori dictionary: http://www.māoridictionary.co.nz/index.cfm 